Journal of African Real Estate Research

Volume 6, Issue 1

Special Issue: Women in African Real Estate and Urban

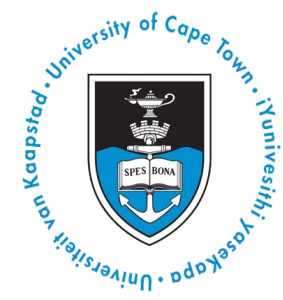

\title{
A Baseline Assessment of Gender Distribution of Government Land Allocation and Privated Tilted Lands in Akure, Nigeria
}

\author{
Mary Adebola Ajayi ${ }^{1}$ \\ ${ }^{1}$ Department of Estate Management, Federal University of Technology Akure, Nigeria
}

To cite this article: Ajayi, M.A. (2021). A Baseline Assessment of Gender Distribution of Government Land Allocation and Privated Tilted Lanks in Akure, Nigeria. Journal of African Real Estate Research, 6(1), pp.1-18. DOI: 10.15641/jarer.v6i1.947.

\begin{abstract}
There is strong evidence that most land transactions in Nigerian urban areas take place in the private or informal land market and remain untitled. Only a small percentage of land transactions take place through government allocation even though it ensures greater tenure security. This study examines gender distribution in the allocation of government lands in Akure, Nigeria and the rate of land title registration in the private land market using secondary data of land allocation and Certificate of Occupancy for a period of 10 years (2009-2018) from the Lands Department of the Ministry of Works, Land and Housing, Akure. Close-ended questionnaires were administered to the officials in charge of the records and the Director of the Department was interviewed. Primary data were analysed using weighted mean scores, while secondary data were analysed using ratio and difference measures, trend analysis and analysis of variance (ANOVA). Findings show that the number of registered land titles in private land was lower than the number of government land allocations even though more transactions took place in the private land market. The time taken to process land title registration and lack of awareness were ranked highest among factors affecting land title registration, while cost of processing was ranked least important. Although there were no gender specific requirements in the process of land allocation and title registration, stereotypes appear to play a role in land distribution decisions and title registration across the study area. A risk ratio of as high as three to one (males to females) in land allocation and 10 to one in land title registration was observed in some years. The paper recommends educating people, especially women, about the importance of land titling and the process of accessing government land, which is far more secure than private land. Recommendations are also made towards a better land registration process in the study area.
\end{abstract}

Keywords: Gender; Government Land; Land Titling; Nigeria; Tenure Security 


\section{Introduction}

The importance of land cannot be over-emphasised. Land contributes significantly to production (agriculture, manufacturing and building construction); and it is a source of power, social prestige, cultural identity and heritage (Lipton, 2009; Odeny, 2013). The customary land tenure system in which land transactions are adminstered by cultural norms is used in about $75 \%$ of land in Africa (Odeny, 2013). In line with this, Rakodi and Leduka (2004) and Durand-Lasserve (2006) believe that more transactions take place in lands held under customary tenure in the private or informal sector than in the formal or public land sector. This means that a greater number of people gain access to land through the informal land market. Nevertheless, much land transacted in the informal land market does not have title registration with the State in the form of a Certificate of Statutory Right of Occupancy (C of $\mathrm{O}$ ) in Nigeria. Hence, the inherent potential in such untitled lands, such as providing security and investment incentive and contributing to financial development by increasing the supply of credit facility, cannot be maximised. Land registration is vital to tenure security, which can lead to land investment, land value appreciation, a reduction in land disputes and litigation costs, a more efficient land market, greater access to credit facilities and efficient redistribution of property (Byamusigha, 1999; De Soto, 2000; Awuah \& Hammond, 2013; Nwuba \& Nuhu, 2018).

This paper examines the rate of land title registration in the informal market and allocation of land by the government by examining land transactions in the informal market that were registered or titled and government land allocation over a period of 10 years in Akure, Nigeria. The paper further examines the gender differentials in both the formal and informal land markets while also looking at factors that hinder land title registration in the city. The research questions are as follows:

1. What are the factors affecting land title registration in the study area?

2. What is the gender distribution of land allocations by the government between 2009 - 2018 ?

3. What is the gender distribution of private titled lands that were issued $\mathrm{C}$ of $\mathrm{O}$ between 2011 - 2018 ?

\section{Literature Review}

The literature review includes the concept of land accessibility and tenure security, empirical studies on land title registration and the legal framework for property ownership by married couples in Nigeria.

\subsection{Concept of Land Accessibility and Tenure Security}

Land access is defined by the United Nations Human Settlement Programme as "opportunities for temporary or permanent use and occupation of land for purposes of shelter, productive activity, or the enjoyment of recreation and rest" (UN-HABITAT, 2008: p.5). This access can be acquired through direct 
occupation, exchange, membership in family and kin groups or by allocation by government or other landowners. Allocation by government, first settlement, conquest, long occupation or market transaction are also identified by Toulmin (2008) as means of accessing land in Africa. Tutu et al. (2016) identify six means of gaining access to land in rural Ghana as inheritance, grant, contractual arrangement or rent, purchase, marriage and gift. Furthermore, Ajayi (2014) confirms the means of gaining access to land in southern Nigeria to include inheritance, purchase, government allocation and gift. There are four elements of land accessibility as conceptualised by Omirin (2002): availability of land, affordability of land, ease of transaction in land and the security of tenure in land. Nwuba (2017) supports this by recognising that having access to land requires availability of usable land with secure tenure that is economically affordable combined with relative ease of transaction.

This paper deals with tenure security as one of the elements of land accessibility because land registration is aimed at securing one's tenure in a piece of land. Tenure security is deemed to be higher in government lands than in private lands. Tenure security is based on the certainty of the bundle of land rights and the certainty that a person's rights to land will be recognised by others and protected in cases of specific challenges (Food and Agriculture Organisation, 2002; Hoekema et al., 2009). The higher the tenure security, the lower is the risk of rights to land being threatened, compromised or eliminated. Place et al. (1994: p.19) state that:

"Land tenure security can be defined to exist when an individual perceives that he or she has rights to a piece of land on a continuous basis, free from imposition or interference from outside sources, as well as ability to reap the benefits of labor and capital invested in that land, either in use or upon transfer to another holder"

People view tenure security differently, hence measuring how secure land is can be subjective and may be measured indirectly. That is, tenure security is what people perceive it to be. Tutu et al. (2016) examined the perception of tenure security in a study on developing a pro-poor approach to land title registration in Juaben-Atia, a rural settlement in Ghana. Of the 53 respondents, $80 \%$ perceived their tenure to be secure due to the absence of boundary disputes. Another 14\% attributed their tenure security to long occupation with no counter claim. Meanwhile, $6 \%$ could not give any reason for their perception of tenure security. Most of respondents (70\%) who were aware of the importance of land title registration, preferred the use of social mechanisms and natural features to secure their farm parcels. Almost half $(46 \%)$ of the respondents believed that taking physical possession of the land rather than records in an official book is enough to secure their tenure at the local level. Additionally, 54\% indicated that recognition of their occupation by the traditional authority was more important to them than recording their interest in a land register.

Despite the much-acclaimed importance of land registration for tenure security, Abdulai (2006) holds a contrary opinion. The author argues that 
increasing security and certainty of tenure does not require land title registration, which is a 'colonial creation', and instead proposes five ingredients of secure and certain land rights: recognition of an individual's land rights by the community, availability of land rights enforcement institutions, ascertained duration of property rights to land, clear definition of property rights in land and clear boundary demarcation of land. Once these ingredients are in place, the assumption that customary land tenure is insecure and uncertain, requiring land title registration as the solution, is untenable. This view is true to some extent, but it does not negate the importance of having a legal title document, which may be required, for instance, to use the property as collateral for credit facility. Even if, as argued, land title registration is not the solution to tenure security, it does provide a written evidence of an interest in land and makes the property more liquid.

\subsection{Empirical Studies of Land Title Registration in Nigeria}

Despite the benefits of land titling, as of 2008 , less than $20 \%$ of land in subSaharan Africa was titled and the portion in West Africa was as low as 2.3\% (Toulmin, 2008). Furthermore, poor people are usually excluded from acquiring title to their land because of the expensive, complex and slow process of land title registration.

The land title registration process in Nigeria creates challenges that often discourage landowners from registering their land. These include slow and laborious manual procedures (characterised by a paper filing and information card system), insecure data storage vulnerable to destruction by termites or fire, lack of integrity and gross administrative inconsistencies in almost all of the 36 states in the federation. In Ojo's (2014) study, end-users (professionals such as lawyers and estate surveyors, and individuals processing title registration) in Akure, Nigeria were dissatisfied with the land title registration process in terms of time required, level of transparency and lack of modern information technology available at the Land Registry. However, end-users were satisfied with the cost of title registration.

Thontheh and Omirin (2015) examined the effectiveness of the Electronic Document Management System (EDMS) used in land registration in Lagos State as part of a land reform. They discovered that the EDMS improved land registration and that the reform resulted in improved tenure security, more confidence in land transactions, centralised and consolidated file storage and a reduction in waiting time for land information. However, the EDMS neither reduced the number of land disputes nor increased the number of applications processed or the amount of revenue generated by the government. It still takes more than 120 days to process title registration with challenges including the high cost of registration, inadequate technical skills and incompetent staff, high land charges, an ambiguous legal framework and institutional problems. Ekemode et al. (2017) examined the factors influencing land title registration practice in Osun-State, Nigeria. Data were collected from a systematic random sample of 520 land title registration applicants, representing 48.1\% of the total applicants for land title/property rights registration in the state. 
The analysis using descriptive and inferential statistical techniques such as frequency distributions, percentages, a Relative Importance Index (RII) and factor analysis revealed that factors such as the high cost of title documentation and corrupt practices of land registry staff had significant influence on the land title/property rights registration process while factors such as suitability of organisational structure and personnel competence/low morale had less influence on land title registration in the study area. The findings of Udo (2017) about operations in Akwa-Ibom State are similar. Title registration is time consuming, tedious and repetitive with high costs and excessive taxes and there is poor communication and collaboration between agencies handling land administration in the state. The study recommends subsidising the cost of registration and using a computer aided system.

Ojo and Olukolajo (2019) studied the constraints associated with registration of secure property rights in Akure, Nigeria. They used factor analysis to extract six factors comprised of 21 variables. The factors are: time involved in achieving land title registration, inappropriate organisation structure, obsolete or archaic process, absence of modern facilities, defective organisational structure and inadequate human capital. The time taken to achieve land title registration, the bureaucratic procedure involved, inappropriate documents, officials' poor knowledge of ICT and poor internet connectivity are among the inhibiting factors. The study recommends introducing a modern Land Information System (LIS) and Geographic Information System (GIS) into the property rights registration process to make data more secure, enhance data storage and provide easy access and retrieval. Nwanekezie and Mendie (2019), while examining the effect of the titling process on property development in Uyo, Nigeria, identify challenges of the process to include high charges, lengthy or unknown duration to obtain title, lack of transparency, unfriendly staff, submitting the same documents to all the units of the Registry, which stems from poor collaboration between the agencies as identified by Udo (2017), and inability of applicants to access the correct information at the appropriate time. The study recommends delegation of the Governor's Consent and reduction in charges.

As an illustration of the problems with its land title registration program, Nigeria ranked 179th out of a total of 183 countries assessed in the 2011 World Bank ranking of nations' property title registration (World Bank, 2011). The assessment also revealed that the Nigerian states have an average of 13 procedures spanning an average of 82 days and costing an average of $20.9 \%$ of the property value involved in land title registration process. The World Bank (2014) further revealed that in states where Governor's Consent is delegated, as recommended by Nwanekezie and Mendie (2019), registration takes 67 days compared to 110 days where it is not delegated.

These studies have dwelled extensively on the challenges in the land title registration processes in Nigeria. The challenges are enormous and similar across the states. However, none of these studies compared the rate of land title registration in the informal market with the rate of government land 
allocation, which is already titled. Also, none examined gender differentials in land title registration.

\subsection{Legal Framework for Land Ownership by Married Couples in Nigeria}

Women are usually among the vulnerable groups when considering land and property issues. Empirical evidence exists of violations of the fundamental human right to own property being perpetrated against women (Human Rights Watch, 2004; Ajayi \& Olotuah, 2005; Njieassam, 2019). In most parts of Africa, land ownership is still seen as a male concern, hence married men usually write only their names on land documents as the household head. This indicates the need for enlightenment as to the importance of joint titling of land by married couples to ensure tenure security for the woman in case of widowhood or divorce (Ajayi \& Olotuah, 2005).

The legal framework for property ownership in Nigeria is derived from British law, specifically, the Married Women's Property Act 1882 of England, a statute that allows a husband or wife to make an application to any judge of the High Court as to acquisition of title to or possession of property. According to Perchstone and Graeys (2016), a husband and wife have equal undivided rights in a property in which they are joint owners. That is, when the title to the property is registered in both of their names, they have equal rights and their powers over the property are exercisable jointly. The husband cannot dispose of or transfer the property by will without the consent of the wife, even after the marriage has been dissolved. Joint ownership also gives survivorship right to the spouse after the demise of the other. The surviving partner receives all the property. Hence, joint titling is a panacea to violation of widows' property rights by in-laws.

In the absence of joint titling, when a marriage is dissolved, the wife can be given one-third of the property. This was confirmed 45 years ago by the case of Egunjobi vs Ogunjobi in the Western State Court of Appeal, Lagos, Nigeria (1976) where the wife's financial contribution to the construction of a house in which the title deeds were in the husband's name was established. The Court of Appeal affirmed the lower court's decision by granting the wife a one-third share of the proceeds of sale of the property in the event of its sale.

There are laws allowing either spouse to apply to the court for a share of the matrimonial assets in Nigeria. However, it is usually the woman who makes such an application because, in most cases, she is financially dependent on her husband and the legal title to land is normally in her husband's name, due to the culture. In a divorce, judges usually pass judgment for the husband to give the wife a lump sum or periodic payments rather than property. There had been very few cases in which married women were granted matrimonial assets upon divorce prior to 2007 (Ashiru, 2007). There is no empirical study to suggest that the situation has changed or improved. 


\section{Research Methodology}

The study area selected is Akure, a growing city located in the southwestern part of Nigeria. Akure is the headquarters of Akure South Local Government Area and the capital of Ondo State. There is rapid population growth and development in the city and, therefore, high demand for land by individuals and corporations.

Both primary and secondary data were collected for this study. All data were collected in August 2019. First, primary data were gathered through the administration of questionnaires to all 20 officials in charge of land titling and through a personal interview with the Director of the Lands Department, who oversees government residential land under the Ministry of Works, Land and Housing, Akure. Weighted mean scores were used to rank the perceptions of respondents as to the importance of the factors impeding land title registration. Secondary data were obtained from the records of government land allocation and $\mathrm{C}$ of $\mathrm{O}$ of private lands issued over a period of 10 years (2009 - 2018). These were analysed using risk ratios and risk difference measures, as suggested by Pedreschi et al. (2008). Data were segregated based on gender.

Risk ratio $=(\mathrm{p} 1 / \mathrm{p} 2)$ where:

- $\quad \mathrm{p} 1=$ number of male allottees of government land or males with $\mathrm{C}$ of $\mathrm{O}$; and

- $\mathrm{p} 2=$ number of female allottees of government land or females with $\mathrm{C}$ of $\mathrm{O}$.

Risk difference $=\mathrm{p} 1-\mathrm{p} 2$.

Trend analysis was used to investigate the percentage change in the number of government land allocations to males and females as well as number of $\mathrm{C}$ of $\mathrm{O}$ between 2009 and 2018. ANOVA was used to examine the mean difference between the gender groups.

\section{Results and Discussion}

\subsection{The Land Title Registration}

Background information for the 20 officials working in the Lands Department of the Ministry of Works, Land and Housing, Akure who completed questionnaires is presented in Table 1. As an experienced group, most having worked for the Lands Department for 11 to 20 years, they are knowledgeable about the operations and processes involved in land title registration and government land allocation. Almost half (40\%) work in the Land Services Section, which handles the allocation of government land to private developers. Meanwhile, 50\% work in the Deemed Rights Section, which processes the $\mathrm{C}$ of $\mathrm{O}$. 
Table 1: Background Information for Lands Department Respondents

\begin{tabular}{|l|c|c|}
\hline \multirow{2}{*}{ Variables } & Responses & $\begin{array}{c}\text { Percentage (\%) } \\
(\mathbf{n = 2 0 )}\end{array}$ \\
\hline \multirow{3}{*}{ Gender } & Male & $40 \%$ \\
\hline \multirow{3}{*}{ Length of Service } & Female & $60 \%$ \\
\cline { 2 - 3 } & $<10$ & $25 \%$ \\
\cline { 2 - 3 } & $11-20$ & $60 \%$ \\
\hline \multirow{3}{*}{ Level } & $20+$ & $15 \%$ \\
\hline \multirow{3}{*}{ Section } & $1-6$ & $25 \%$ \\
\cline { 2 - 3 } & $7-12$ & $45 \%$ \\
\cline { 2 - 3 } & $13+$ & $30 \%$ \\
\cline { 2 - 3 } & Land services & $40 \%$ \\
\cline { 2 - 3 } & Deemed rights & $50 \%$ \\
\cline { 2 - 3 } & Deed registry & $10 \%$ \\
\hline
\end{tabular}

According to the Director of the Lands Department, all applicants who met the requirements for the allocation of government land were granted allocations irrespective of gender. The requirements include a photocopy of current tax clearance certificate, Ondo State Development Receipt and a passport photograph. A Certificate of Incorporation is required for a corporate body or entity. These documents are attached to the application form, which is obtained from the Ministry for a fee.

Officials working in the Lands Department were asked to rate how strongly they agreed that four factors inhibit land title registration. The responses were converted to a numerical scale of 1 to 5 . The weighted mean scores and ranking of the factors affecting the land title registration are presented in Table 2 .

Table 2: Factors Hindering Land Title Registration in Akure According to Lands Department Officials

\begin{tabular}{|l|c|c|c|c|c|c|c|}
\hline Factor & $\begin{array}{c}\text { Strongly } \\
\text { Agree }\end{array}$ & Agree & Undecided & Disagree & $\begin{array}{c}\text { Strongly } \\
\text { Disagree }\end{array}$ & Mean & Rank \\
\hline Lack of awareness & 8 & 9 & 0 & 2 & 0 & 4.21 & 1 \\
\hline Time required & 4 & 14 & 0 & 1 & 0 & 4.11 & 2 \\
\hline Bureaucracy & 5 & 10 & 2 & 2 & 0 & 3.95 & 3 \\
\hline Cost of processing & 3 & 8 & 2 & 3 & 3 & 3.26 & 4 \\
\hline
\end{tabular}

Note: $n=19$

Questionnaires were administered to 20 staff but only 19 filled the section about factors that affect the land title registration. The respondents believed the factors that most likely hinder title registration are the time taken for the registration and lack of awareness of the importance of title registration. Bureaucracy or long processing follows with a weighted mean score of 3.95. The least important factor is cost of processing. 
While the Director reported that the normal time for processing is within three months, processing may take longer because of incomplete documentation presented by the applicant and the decision of the current State Government to sign or delegate the signing of the document. The paperwork requirements are not gender specific, but a tax clearance certificate may be alien to lowand middle-income earners, who are predominantly women working in the informal sector.

The perceived lack of importance of cost agrees with the findings of Ojo (2014) and Ojo and Olukolajo (2019) in Akure, but is contrary to the finding of Nwanekezie and Mendie (2019) where cost was the most important factor in Uyo. The requirement for three years' tax clearance may be beyond the reach of low- and middle-income informal workers. Also, the cost of processing title documents depends on the size of the land and the purpose for which the land will be used. The cost for residential property was N45,000 per plot and commercial property was $\mathrm{N} 85,000$ per plot at the time of the study while land for agricultural purpose was charged a lower cost to encourage farmers. (US $\$ 1=\mathrm{N} 360$ at the time of data collection).

\subsection{Government Land Allocation}

Secondary data consisting of allocation records of government land and C of $\mathrm{O}$ between 2009 and 2018 were used to examine gender differences. Figure 1 shows that there was a consistently higher number of land allocations made to males over the years. Of the 2,726 plots allocated over the 10-year period, only $29.6 \%$ were allocated to females. Total allocations were highest in 2015 and lowest in 2018 when $24.7 \%$ of the allocations were to females. Joint ownership was generally low in the study area.

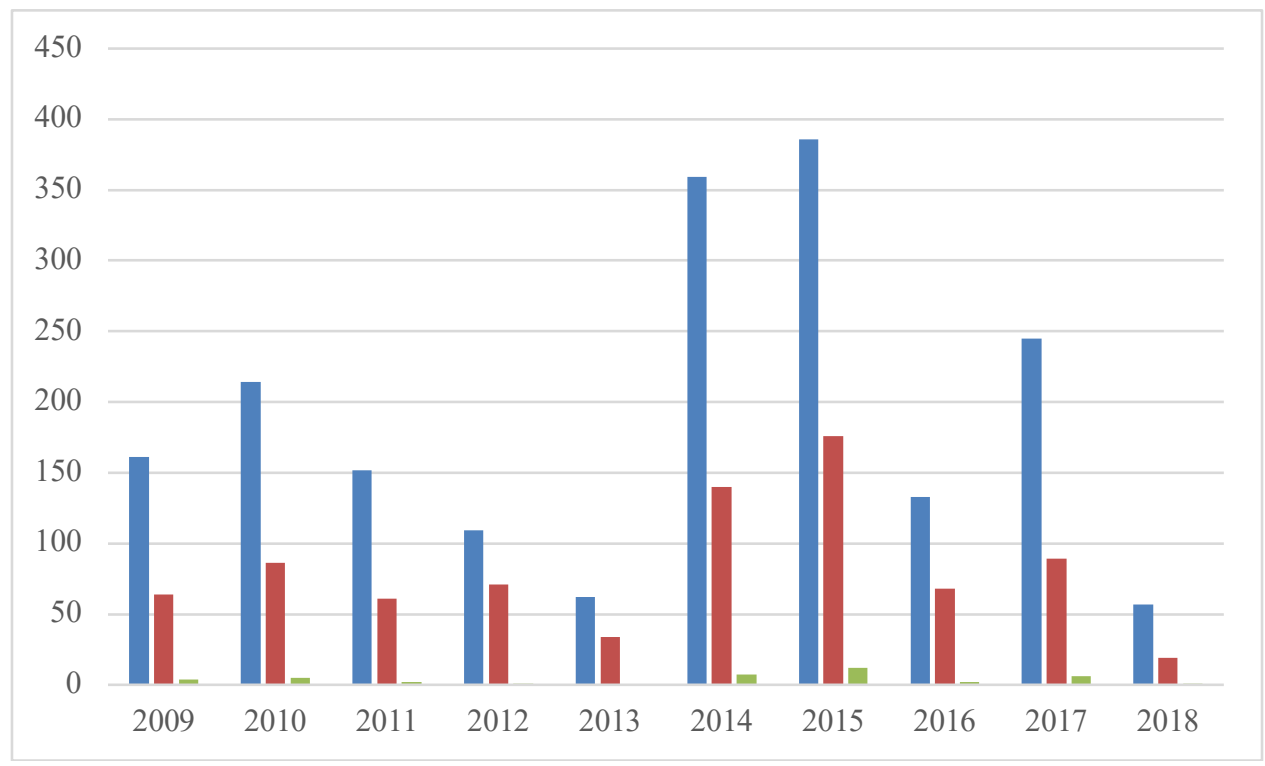

Figure 1: Number of Parcels Allocated in Government Land in Akure 2009-2018

Data Source: Lands Department, Ministry of Works, Lands and Housing, Akure 
The smallest difference between male and female land allocation occurred in 2013 at 28 plots in favour of males while in 2014 the highest difference was 219 plots in favour of males, as shown in Table 3. There was no year when females received a higher number of plots than males. The risk ratio for male versus female government land allocation was lowest in 2012 at 1.5 and highest in 2018 at 3.0. This means for every female receiving a plot allocation, there were three males who were allocated plots in that year.

Table 3: Gender Risk Difference and Ratio Measures of Government Land Allocation in Akure 2009-2018

\begin{tabular}{|l|c|c|c|c|}
\hline \multirow{2}{*}{ Year } & \multicolumn{2}{|c|}{ Number of Land allocations } & Risk difference & Risk Ratio \\
\cline { 2 - 5 } & Male (p1) & Female (p2) & (p1-p2) & (p1/p2) \\
\hline $\mathbf{2 0 0 9}$ & 161 & 64 & 97 & 2.5 \\
\hline $\mathbf{2 0 1 0}$ & 214 & 86 & 128 & 2.5 \\
\hline $\mathbf{2 0 1 1}$ & 152 & 61 & 91 & 2.5 \\
\hline $\mathbf{2 0 1 2}$ & 109 & 71 & 38 & 1.5 \\
\hline $\mathbf{2 0 1 3}$ & 62 & 34 & 28 & 1.8 \\
\hline $\mathbf{2 0 1 4}$ & 359 & 140 & 219 & 2.6 \\
\hline $\mathbf{2 0 1 5}$ & 386 & 176 & 210 & 2.2 \\
\hline $\mathbf{2 0 1 6}$ & 133 & 68 & 65 & 2.0 \\
\hline $\mathbf{2 0 1 7}$ & 245 & 89 & 156 & 2.8 \\
\hline $\mathbf{2 0 1 8}$ & 57 & 19 & 38 & 3.0 \\
\hline
\end{tabular}

For a trend analysis, Table 4 shows the nominal and percentage changes in the allocation of land to males and females over the 10-year period. As illustrated in Figure 1, the change over the years was undulating, that is, increasing and decreasing, a pattern that is likely connected with the political and economic changes in the country. There was a marked increase in the number of allocations to both males and females in 2014 and 2015. This could be a consequence of the consolidation of the state government in its second term of office and the level of prosperity in the economy at the time. The government attempted to stabilise the economy of the state through prompt payment of salaries. As Ondo State is primarily a civil service state and incomes are mainly government salaries, non-payment of salaries to the civil servants would have a ripple effect on all sectors of the economy in the state.

A sharp negative change is observed in 2016 and 2018 for both male and female allocations. This could be because the tenure of the sitting governor was coming to an end in February 2017. Although government should be a continuum, it has been observed in Nigeria that when the tenure of a political officer ends, it takes a while for the new tenure to stabilise economically. Notably, it was only in 2012 that there was an increase in allocations for females $(16.4 \%)$ and a simultaneous decrease for males $(28.3 \%)$. Even so, the land allocation for males was still higher than for females at 109 and 71, respectively. Figure 2 is a graphical representation of the change in government land allocation to males and females shown in Table 4. 
Table 4: Nominal and Percentage Annual Changes in Government Land Allocation in Akure 2009-2018 by Gender

\begin{tabular}{|l|c|c|c|c|c|c|}
\hline \multirow{3}{*}{ Year } & \multicolumn{5}{|c|}{ Land Allocations } \\
\cline { 2 - 7 } & \multicolumn{5}{|c|}{ Male } & \multicolumn{3}{c|}{ Female } \\
\cline { 2 - 7 } & Number & Change & \% change & Number & Change & \% change \\
\hline 2009 & 161 & - & - & 64 & - & - \\
\hline 2010 & 214 & 53 & $32.9 \%$ & 86 & 22 & $34.4 \%$ \\
\hline 2011 & 152 & -62 & $-29 \%$ & 61 & -25 & $-29.1 \%$ \\
\hline 2012 & 109 & -43 & $-28.3 \%$ & 71 & 10 & $16.4 \%$ \\
\hline 2013 & 62 & -47 & $-43.1 \%$ & 34 & -37 & $-52.1 \%$ \\
\hline 2014 & 359 & 297 & $479 \%$ & 140 & 106 & $311.8 \%$ \\
\hline 2015 & 386 & 27 & $7.5 \%$ & 176 & 36 & $25.7 \%$ \\
\hline 2016 & 133 & -253 & $-65.5 \%$ & 68 & -108 & $-61.4 \%$ \\
\hline 2017 & 245 & 112 & $84 . \%$ & 89 & 21 & $30.9 \%$ \\
\hline 2018 & 57 & -188 & $-76.7 \%$ & 19 & -70 & $-78.7 \%$ \\
\hline
\end{tabular}

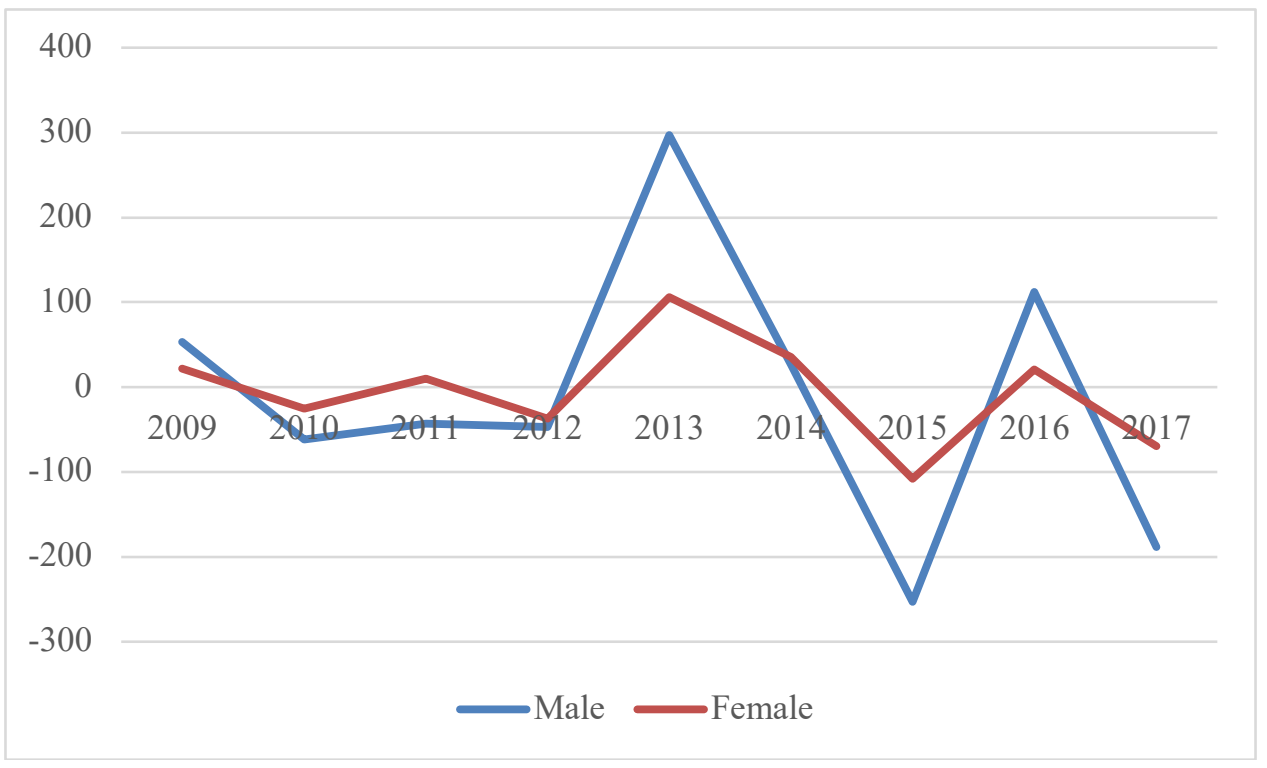

Figure 2: Annual Change in Number of Government Land Allocations in Akure 2009-2018 by Gender

ANOVA results in Table 5 show that there is a significant difference in the mean annual number of plots allocated to the male, female and joint title groups of allottees for the period of study. The post hoc test results in Table 6 further show that the difference in the average number of allocations to males and females as well as difference between male and joint title allocations is significant. There is no significant difference (at the 5\% level) in the means of female and joint title allocations. 
Table 5: ANOVA of Annual Government Land Allocation Between Male, Female and Joint Titles 2009-2018

\begin{tabular}{|l|c|c|c|c|c|}
\hline & $\begin{array}{c}\text { Sum of } \\
\text { squares }\end{array}$ & Df & $\begin{array}{c}\text { Mean } \\
\text { square }\end{array}$ & F & Sig. \\
\hline $\begin{array}{l}\text { Between } \\
\text { Groups }\end{array}$ & 170432.27 & 2 & 85216.13 & 16.86 & 0.000 \\
\hline $\begin{array}{l}\text { Within } \\
\text { Groups }\end{array}$ & 136423.20 & 27 & 5052.71 & & \\
\hline Total & $\mathbf{3 0 6 8 5 5 . 4 7}$ & $\mathbf{2 9}$ & & & \\
\hline
\end{tabular}

Table 6: Tukey HSD Post Hoc Test of Difference in Annual Government Land Allocations in Akure 2009-2018 by Gender

\begin{tabular}{|l|l|c|c|c|}
\hline \multicolumn{2}{|l|}{ Groups } & $\begin{array}{c}\text { Mean } \\
\text { Difference }\end{array}$ & $\begin{array}{c}\text { Standard } \\
\text { Error }\end{array}$ & Sig. \\
\hline Male & Female & $107.000^{*}$ & 31.79 & .006 \\
\hline Male & Joint & $183.800^{*}$ & 31.79 & .000 \\
\hline Female & Joint & 76.800 & 31.79 & .057 \\
\hline
\end{tabular}

Note: *The mean difference is significant at 0.05 level.

\subsection{Certificates of Occupancy (C of O)}

$\mathrm{C}$ of O records were available for 2012 to 2018. Earlier years could not be assessed due to manual record keeping. A total of $912 \mathrm{C}$ of $\mathrm{O}$ were issued within the seven years for which records are available. Out of these, 74.1\% were issued to males while $25.9 \%$ were issued to females. Joint titles were counted as male and not recorded separately. Figure 3 shows that a consistently higher number of males received $\mathrm{C}$ of $\mathrm{O}$ over the years. The highest absolute number and relative percentage of $\mathrm{C}$ of $\mathrm{O}$ were given to males in 2013 (192 or $90.6 \%$ ). The smallest number of $\mathrm{C}$ of $\mathrm{O}$ were issued in 2014 with males receiving 57, which was still more than half of the total number of $\mathrm{C}$ of $\mathrm{O}$ issued that year. The year with the highest number of $\mathrm{C}$ of $\mathrm{O}$ issued to females was 2012 at 58 or $35.4 \%$ of the total number that year. 


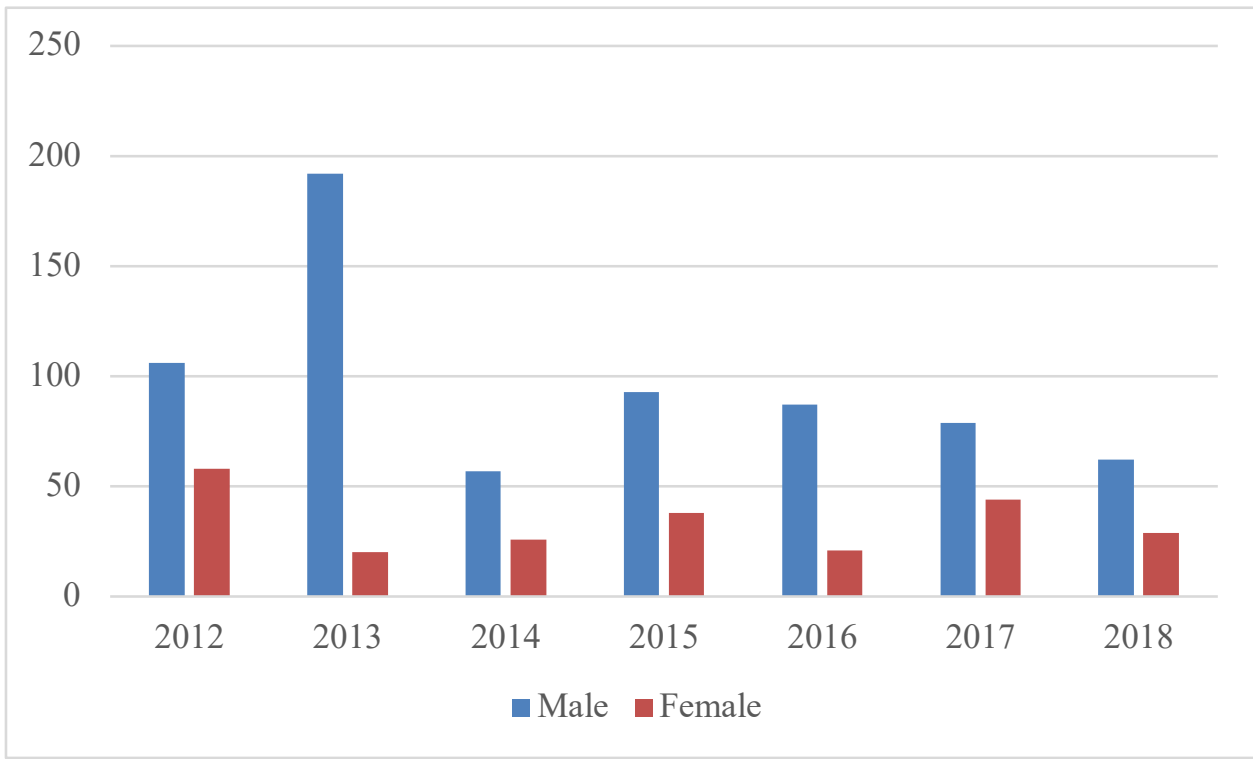

Figure 3: Number of $C$ of $O$ Issued on Private Lands in Akure 20122018 by Gender

Source: Lands Department, Ministry of Works, Lands and Housing, Akure

Table 7 shows the difference in the number of $\mathrm{C}$ of $\mathrm{O}$ processed for males (including joint titles) and females from 2012 to 2018. The smallest difference between the number of $\mathrm{C}$ of $\mathrm{O}$ issued to males and females occurred in 2014 at 31 certificates in favour of males while the previous year recorded the largest difference at 172 more certificates for males. There was no year when females received more $\mathrm{C}$ of $\mathrm{O}$ than males. The risk ratio was lowest in 2012 and 2017 at 1.8 and highest in 2013 at 9.6. This means that for every female who processed a $\mathrm{C}$ of $\mathrm{O}$ in 2013 , there were approximately 10 males with $\mathrm{C}$ of $\mathrm{O}$.

Table 7: Gender Risk Difference and Ratio Measures of $\mathrm{C}$ of $\mathrm{O}$ Issued on Private Lands in Akure 2012-2018

\begin{tabular}{|l|c|c|c|c|}
\hline \multirow{2}{*}{ Year } & \multicolumn{2}{|c|}{ Number of C of O } & $\begin{array}{c}\text { Risk } \\
\text { difference }\end{array}$ & Risk ratio \\
\cline { 2 - 5 } & Male & $\begin{array}{c}\text { Female } \\
(\mathbf{p} 1)\end{array}$ & (p1-p2) & (p1/p2) \\
\hline 2012 & 106 & 58 & 48 & 1.8 \\
\hline 2013 & 192 & 20 & 172 & 9.6 \\
\hline 2014 & 57 & 26 & 31 & 2.2 \\
\hline 2015 & 93 & 38 & 55 & 2.5 \\
\hline 2016 & 87 & 21 & 66 & 4.1 \\
\hline 2017 & 79 & 44 & 35 & 1.8 \\
\hline 2018 & 62 & 29 & 33 & 2.1 \\
\hline
\end{tabular}

Table 8 shows the annual nominal and percentage changes in the $\mathrm{C}$ of $\mathrm{O}$ issued to males and females over the seven-year period. The percentage annual change in the number of processed $\mathrm{C}$ of $\mathrm{O}$ by gender are illustrated in Figure 4. The largest annual increase for males of $81.1 \%$ occurred from 2012 
to 2013 whereas $\mathrm{C}$ of $\mathrm{O}$ issued to females decreased by $65.5 \%$ during the same time period. The following year, 2014, recorded the largest decrease for males (135) while females were issued 6 more $\mathrm{C}$ of $\mathrm{O}$ than the previous year. The largest increase for females occurred in 2017 when 23 more $\mathrm{C}$ of $\mathrm{O}$ were issued than the previous year, a $109.4 \%$ increase. This increase could be a result of the change of power in the state government in 2017.

Table 8: Nominal and Percentage Annual Changes in $\mathrm{C}$ of $\mathrm{O}$ Issued on Private Lands in Akure 2012-2018 by Gender

\begin{tabular}{|l|c|c|c|c|c|c|}
\hline \multirow{2}{*}{} & \multicolumn{5}{|c|}{ Year } & \multicolumn{5}{|c|}{ Cof O } \\
\cline { 2 - 7 } & Number & Change & \% Change & Number & Change & $\%$ Change \\
\cline { 2 - 7 } & 106 & - & - & 58 & - & - \\
\hline $\mathbf{2 0 1 2}$ & 192 & 86 & $81.1 \%$ & 20 & -38 & $-65.5 \%$ \\
\hline $\mathbf{2 0 1 3}$ & 57 & -135 & $-70.3 \%$ & 26 & 6 & $30 \%$ \\
\hline $\mathbf{2 0 1 4}$ & 93 & 36 & $63.2 \%$ & 38 & 12 & $46.2 \%$ \\
\hline $\mathbf{2 0 1 5}$ & 87 & -6 & $-6.5 \%$ & 21 & -17 & $-44.7 \%$ \\
\hline $\mathbf{2 0 1 6}$ & 79 & -8 & $-9.2 \%$ & 44 & 23 & $109.5 \%$ \\
\hline $\mathbf{2 0 1 7}$ & 62 & -17 & $-21.5 \%$ & 29 & -15 & $-34.1 \%$ \\
\hline $\mathbf{2 0 1 8}$ & & & & & & \\
\hline
\end{tabular}

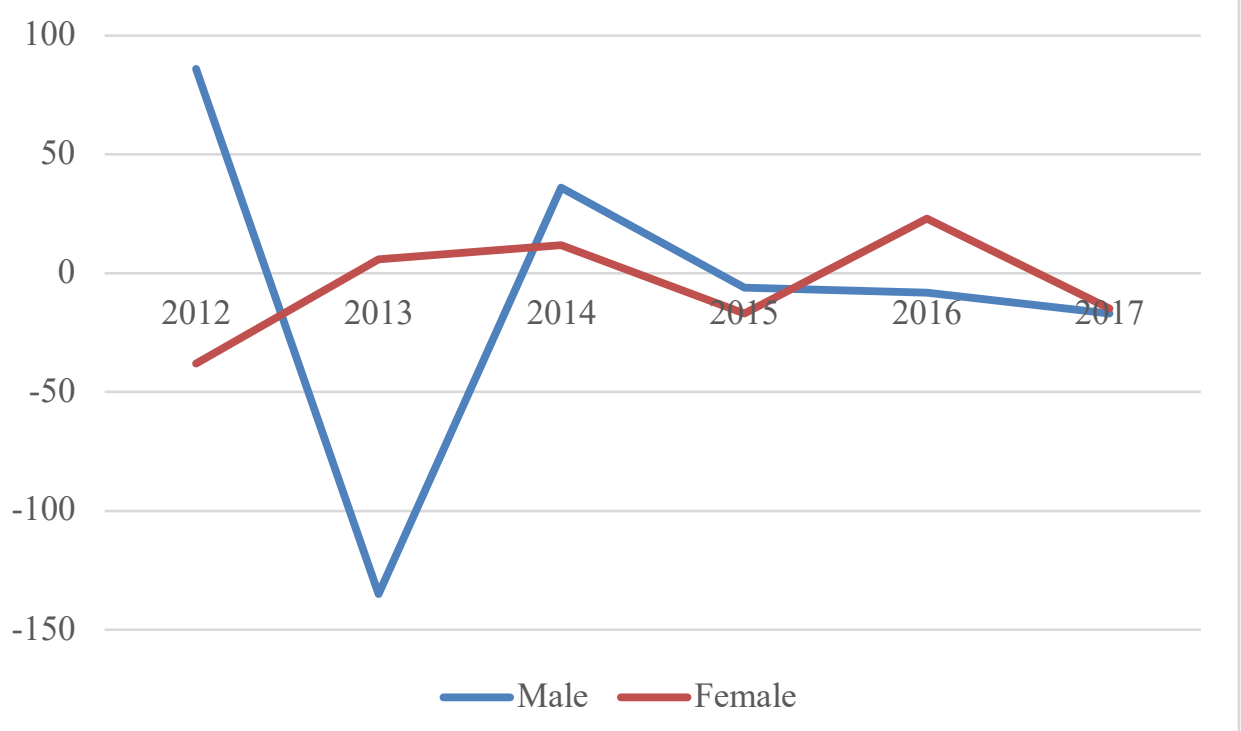

Figure 4: Annual Change in the Number of $\mathrm{C}$ of $\mathrm{O}$ Processed on Private Lands in Akure 2012-2018 by Gender

The ANOVA results in Table 9 show that there is a significant difference in the mean annual number of $\mathrm{C}$ of $\mathrm{O}$ processed for males and females during the period under consideration. 
Table 9: ANOVA of Mean Annual Number of Certificates of Occupancy Issued for Males and Females in Akure, 2012-2018

\begin{tabular}{|l|c|c|c|c|c|}
\hline & $\begin{array}{c}\text { Sum of } \\
\text { Squares }\end{array}$ & Df & $\begin{array}{c}\text { Mean } \\
\text { Square }\end{array}$ & F & Sig. \\
\hline $\begin{array}{l}\text { Between } \\
\text { Groups }\end{array}$ & 13828.571 & 1 & 13828.571 & 12.278 & .004 \\
\hline $\begin{array}{l}\text { Within } \\
\text { Groups }\end{array}$ & 13515.143 & 12 & 1126.262 & & \\
\hline Total & 27343.714 & 13 & & & \\
\hline
\end{tabular}

A major finding of the study is that the number of titled private lands is lower than the number of plots allocated by the government. Although a greater percentage of land transactions take place in the private land market (Rakodi \& Leduka, 2004; Durand-Lasserve, 2006), only few of them are titled. The analysis confirms that females obtain land titles less often than males and the idea of joint ownership is not yet popular in the study area.

\section{Conclusion and Recommendations}

This paper examines government land allocation and title registration of private lands using the records of the Lands Department, Ministry of Works, Lands and Housing, Akure, for a period of 10 and seven years, respectively. The records show that government land allocation is greater than registered private land even though a greater number of transactions take place in the private land market. This shows that little importance is attached to title registration. Time taken in processing the $\mathrm{C}$ of $\mathrm{O}$ and lack of awareness were ranked as the greatest hinderance while cost of processing was ranked as the least hinderance to title registration by Lands Department officials. There is need for upgrading the Land Registry with modern ICT to improve the quality of services and reduce the time taken for processing.

Although the requirements for land allocation were not gender specific, there were consistently higher numbers of allocations of government land to males than females over the period under review with a Risk Ratio of 3:1 for males to females in the most recent year of data. This means that three males were allocated plots for every female that was allocated a plot in 2018. The title registration Risk Ratio was higher, even reaching 10:1 in 2013, pointing to lower tenure security for women. Both positive and negative changes were observed in the pattern of male and female land allocation which could be linked to the change of power in government and fluctuating economy of the State.

The number of joint titles was very low and this confirms the traditional practice of buying and registering land in a man's name. As women are predominantly in the informal sector, which is characterised by non-payment of tax, the requirement of tax clearance certificate might be a likely obstacle to low-income workers in the informal sector to registering their land titles. 
As a result of the study, we recommend sensitisation (creating awareness) of the citizens, especially women, through their various networks on the availability and process of acquiring government land. With the existence of discriminatory cultural practices in the informal land market, women should be enlightened and encouraged to take advantage of government land, which is more secure. Government officials should seek to reduce the impact of political changes leading to delay in getting Governor's Consent in the process of land title registration. Practicing Estate Surveyors and Valuers in the state should educate their clients of the availability and requirements of government land allocation and the importance of having registered land titles.

Further studies can be conducted on the level of awareness of property owners in the study area on the importance of land registration. This study can also be replicated in other states in the country, especially in big cities like Lagos and Abuja where many land transactions take place.

\section{References}

Abdulai, R.T. (2006). Is land title registration the answer to insecure and uncertain property rights in sub-Saharan Africa? RICS Research Paper Series, 6(6), pp.1-27.

Ajayi, M.A. \& Olotuah, A.O. (2005). Violation of women's property rights within the family. Agenda No. 66, Gender-Based Violence Trilogy, 1(1), pp.58-63.

Ajayi, M. A. (2014). Gender access to land and housing in Southern Nigeria. $\mathrm{PhD}$ Thesis. Department of Estate Management, Federal University of Technology, Akure, Nigeria.

Ashiru, M.O.A. (2007). Gender discrimination in the division of property on divorce in Nigeria, Journal of African Law, 51(2), pp.316-331.

Awuah, K.G.B. \& Hammond, F.N. (2013). Prognosis of land title formalization in urban Ghana: the myth and reality of awareness and relevance, African Studies Quarterly, 14(1 \& 2), pp.55-75.

Byamusigha, F.F.K. (1999). The effects of land registration on financial development and economic growth. World Bank Policy Research Working Paper 2240.

De Soto, H. (2000) The Mystery of Capital: Why Capitalism Triumphs in the West and Fails Everywhere Else. New York: Basic Books.

Durand-Lasserve, A. (2006). Informal settlements and the Millennium Development Goals: Global policy debates property ownership and security of tenure, Global Urban Development, 2(1), pp.1-15.

Egunjobi vs Ogunjobi, Western State Supreme Court of Appeal (1976). FNLR 78.

Ekemode, B.G., Adegoke, O.J. \& Aderibigbe, A. (2017). Factors influencing land title registration practice in Osun State, Nigeria. International Journal of Law in the Built Environment, 9(3), pp.240-255. 
Federal Republic of Nigeria. (2007). Legal notice on publication of the details of the breakdown of the national and state provisional totals 2006 census. Federal Government Printer: Lagos, Nigeria.

Food and Agriculture Organisation. (2002). Gender and access to land. FAO Land Tenure Studies 4, Rome: FAO.

Hoekeman, A.J., Ubink, J.M. \& Assies, W.J. (2009). Legalising Land Rights: Local Practices, State Responses and Tenure Security in Africa, Asia and Latin America. Leiden: Leiden University Press.

Human Rights Watch. (2004) Women property right: violation dooms equality and development. [Online]. Available at: http://www.hrw.org//campaign/women/property.

Lipton, M. (2009). Land Reform in Developing Countries: Property Rights and Property Wrongs. New York: Routledge.

Njieassam, E.E. (2019). Gender inequality and land rights: the situation of indigenous women in Cameroon. PER/PELJ, 22, pp.1-33. DOI: $10.17159 / 1727-3781 / 2019 / \mathrm{v} 22 \mathrm{i} 0 \mathrm{a} 4907$

Nwanekezie, O.F. \& Mendie, E.A. (2019). An investigation of effect of titling processes on property development in Uyo, Nigeria. American Journal of Economics, 9(4), pp.207-212.

Nwuba, C.C. (2017). Access to land as a constraint to homeownership in Kaduna State, Nigeria. In proceedings of the 7th West Africa Built Environment Research (WABER) Conference, Accra, Ghana, 16-18 August 2017. pp.140-159.

Nwuba, C.C. \& Nuhu, S.R. (2018). Challenges to land registration in Kaduna State, Nigeria. Journal of African Real Estate Research, 1(1), pp.141172.

Odeny, M. (2013). Improving access to land and strengthening women's land rights in Africa. Paper prepared for presentation at the Annual World Bank Conference on Land and Poverty. Washington DC: The World Bank Group.

Ojo, B. (2014). Evaluation of end users' satisfaction on land title registration process in Akure, Nigeria. Covenant Journal of Research in the Built Environment, 2(2), pp.176- 189.

Ojo, B. \& Olukolajo M.A. (2019). Analysis of constraints with access to secure property rights registration in Akure, Nigeria, Journal of Technology Management and Business, 6(2), pp.1-10.

Omirin, M.M. (2002). Issues in land accessibility in Nigeria. Proceedings of the National Workshop on Land Management and Property Tax Reform in Nigeria. Department of Estate Management, University of Lagos, Nigeria

Pedreschi, D., Ruggieri, S. \& Turini, F. (2008). Measuring discrimination in socially-sensitive decision records. Procedure of SIAM ICDM, Dipartimento di Informatica, Universit'a di Pisa.

Perchstone \& Graeys. (2016). Nigeria: Joint ownership in context of marriage. Lagos, Nigeria. [Online]. Available at: https://www.mondaq.com/nigeria/divorce/504008/joint-ownershipin-context-of-marriage.

Place, F., Roth, M. \& Hazell, P. (1994). Land tenure security and agricultural 
performance in Africa: overview of research methodology. In J.W. Bruce \& S.E. Migot-Adholla (Eds), Searching for Land Tenure Security in Africa, pp.15-39. Dubuque: Kendall/Hunt Publishers.

Thontheh, E.O., \& Omirin, M.M. (2015). Land registration within the framework of land administration reform in Lagos State. Proceedings of the 21st Annual Pacific-Rim Real Estate Society Conference, Malaysia, 18-21 January.

Toulmin, C. (2008). Securing land and property rights in Sub-Saharan Africa: the role of local institutions, Land Use Policy, 26, pp.10-19.

Tutu D. O., Asante, L.A., Appiah, M.N., Bendzko, T. \& Chigbu, U.E. (2016). Towards a pro-poor customary land rights security in rural Ghana: land tenure inventory using mobile application by local youth. Paper prepared for presentation at the 2016 World Bank Conference on Land and Poverty, 14-18 ${ }^{\text {th }}$ March. Washington DC: The World Bank Group.

Udo, U.I. (2017). An evaluation of land administration and its implications on housing delivery in Akwa Ibom State. Unpublished M.Sc. Dissertation. University of Uyo, Uyo, Nigeria.

UN-HABITAT. (2008). Secure Land for All. Nairobi: UN-HABITAT.

World Bank. (2011). Doing business 2011: Making a difference for entrepreneurs. Washington DC: The World Bank Group.

World Bank. (2014). Doing Business in Nigeria 2014: Understanding Business Regulations for Small and Medium-Size Enterprises. [Online]. Washington DC: The World Bank Group.Available at: https://openknowledge.worldbank.org/handle/10986/21970 